\title{
Two New Species of Vestimentiferan Tubeworm (Polychaeta: Siboglinidae a.k.a. Pogonophora) from the Brothers Caldera, Kermadec Arc, South Pacific Ocean
}

\author{
Tomoyuki Miura ${ }^{1}$ and Shigeaki Kojima ${ }^{2}$ \\ ${ }^{1}$ Faculty of Agriculture, University of Miyazaki, 1-1 Gakuen-Kibanadai-Nishi, \\ Miyazaki, 889-2192 Japan \\ E-mail:miurat@cc.miyazaki-u.ac.jp \\ ${ }^{2}$ Ocean Research Institute, University of Tokyo, 1-15-1 Minamidai, \\ Tokyo, 164-8639 Japan \\ E-mail:kojima@ori.u-tokyo.ac.jp
}

(Received 1 September 2005; Accepted 8 April 2006)

\begin{abstract}
Two new species of vestimentiferan tubeworm collected from the Brothers Caldera in the Kermadec Arc, South Pacific Ocean, are described here, based on morphological and molecular analyses, including sequence comparisons of over $600 \mathrm{bp}$ of the mitochondrial COI gene. Lamellibrachia juni sp. nov. differs from congeneric species in having flexible and thin-walled tubes, up to three pairs of lamellar sheaths, and similarly sized cuticular plaques on the vestimentum and trunk. Oasisia fujikurai sp. nov. differs from its sole congener in having eight pairs of branchial lamellae instead of up to 20 . Oasisia and Ridgeia are shown likely to constitute a monophylum, but are retained as separate genera for now. The relationships between this clade and the genera Tevnia and Riftia remain unresolved. Within the monophyletic genus Lamellibrachia, L. juni sp. nov, is closest to L. sp. L7 from the Manus Basin.

Key Words: Brothers Caldera, Kermadec Arc, Polychaeta, Vestimentifera, Lamellibrachia, Oasisia, Ridgeia, COI gene sequence, taxonomy, monophyly.
\end{abstract}

\section{Introduction}

More than 30 years of deep-sea research using scientific submersibles have provided a rich supply of vestimentiferan tubeworm material and led to the description of numerous new taxa in this group from the species to the phylum level (Webb 1969; Van der Land and Nørrevang 1975; Jones 1985; Southward et al. 2002), but morphological analysis alone may not be ideal for vestimentiferan taxonomy. Confusion in interpreting morphological changes during growth, as well as individual variation, resulted in the description of an invalid species, which was subsequently synonymized with another species of the same genus after observations had been carried out on additional specimens (Jones 1985; Southward et al. 1995). The unique ecology and body structures of deep-sea vestimentiferans have stimulated a number of molecular and cladistic analyses leading to numerous phylogenetic cladograms for vestimentiferan tubeworms (Williams et al. 1993; McHugh 1997; Black et al. 1997; Rouse and Fauchald 1997; Kojima 1998; Halanych et al. 1998; 
Rouse 2001; Gardiner et al. 2001; Kojima et al. 2001, 2002, 2003; Hurtado et al. 2002; Schulze 2003; McMullin et al. 2003; Andersen et al. 2004). But molecular data alone may also be insufficient. For example, in the case of the genus Escarpia, the COI (cytochrome oxidase $c$ subunit I) sequences cannot discriminate the three included nominal species (Anderson et al. 2004).

During the YK04-9 SWEEPVENTS Cruise of R/V Yokosuka of the Japan Agency for Marine-Earth Science and Technology (JAMSTEC) in 2004, hydrothermal vent fields in the Brothers Caldera in the Kermadec Arc were surveyed using the submersible Shinkai 6500. In a single hydrothermal vent field on the northwestern wall of the caldera, where acidic (around pH2) and Al-rich hydrothermal fluid was sampled (de Ronde et al. 2005), two kinds of vestimentiferan worm were discovered. Larger worms belonging to the genus Lamellibrachia thickly colonized a soft substrate in proximity to a hydrothermal vent, while a smaller species of the genus Oasisia made dense clumps on a sulfide structure with diffuse flow. Here we use both morphological and molecular analyses to describe these two new species.

\section{Materials and Methods}

Vestimentiferan specimens were collected from the Brothers Caldera in the Kermadec Arc at about $1600 \mathrm{~m}$ depth. The manipulator arm of DSRV Shinkai 6500 was used to remove tubeworms from the substratum and place them into an external cage attached to the submersible; they were brought up to the surface without any regulation of pressure. The sampling data are provided in the taxonomic section below. Most of the examined specimens were fixed aboard ship in $10 \%$ seawater formalin and preserved in 70\% ethyl alcohol, and the rest were preserved in $99 \%$ ethyl alcohol without formalin fixation. Nine additional specimens of Oasisia were used only for measurement of their tubes, because the badly fixed soft bodies were not suitable for measurements or other observations. Specimen drawings and photographs were made respectively with the aid of a camera lucida (Olympus SZX-DA) and a digital camera system (Nikon Coolpix 950) attached to a dissecting microscope (Olympus SZX12). Additional morphological observations were made with a light microscope (Olympus BH2). The type specimens are deposited in the National Science Museum, Tokyo (NSMT). The polychaete classification proposed by Rouse and Fauchald (1997) is basically followed in this study. In this classification, all pogonophores and vestimentiferan tubeworms are placed in the family Siboglinidae.

Three specimens of each species were taken from the same haul as their type specimens for DNA studies. In the laboratory DNA was extracted from the vestimentum by grinding, digestion with sodium dodecyl sulfate, and extraction with phenol and chloroform. An approximately 700 base-pair (bp) segment of the mitochondrial gene for COI was amplified by the polymerase chain reaction (PCR) with the universal COI primers LCO1490 (5'-GGTCAACAAATCATAAAGA TATTGG-3') and HCO2198 (5'-TAAACTTCAGGGTGACCAAAAAATCA-3') (Folmer et al. 1994). PCR conditions were as follows: $94^{\circ} \mathrm{C}$ for $60 \mathrm{~s}$; then 30 to 40 cycles at $92^{\circ} \mathrm{C}$ for $40 \mathrm{~s}$, $50^{\circ} \mathrm{C}$ for $60 \mathrm{~s}$, and $72^{\circ} \mathrm{C}$ for $90 \mathrm{~s}$. Genereleaser ${ }^{\mathrm{TM}}$ (BioVenture Inc., Murfreesboro, TN, USA) was used to sequester products of cell lysis that might have inhibited the polymerase. 
The nucleotide sequence of $630 \mathrm{bp}$ of each amplified fragment was determined bidirectionally with an automated sequencer (ABI3100; Applied Biosystems Inc., Foster City, CA, USA) using the same primers as those for PCR.

The genetic distance between sequences was calculated by Kimura's twoparameter method (Kimura 1980). Phylogenetic trees were constructed by the neighbor-joining (NJ) method (Saitoh and Nei 1987) with the program from the MEGA2 package, Version 2.1 (Kumar et al. 2001) and the maximum-parsimony (MP) method using the multiple equally parsimonious heuristic search option of PAUP, Version 4.0b10 (Swofford 2002), with tree bisection-reconnection and 1000 random addition sequence replicates.

\section{Taxonomic Account}

Family Siboglinidae Caullery, 1914

Genus Lamellibrachia Webb, 1969

Lamellibrachia juni sp. nov.

(Figs 1, 2, Tables 1, 2)

Material examined. Holotype: Brothers Caldera, Shinkai 6500 Dive 851, 26 October $2004,34^{\circ} 51.652^{\prime} \mathrm{S}, 179^{\circ} 03.536^{\prime} \mathrm{E}, 1604 \mathrm{~m}$, female, NSMT-Pc 9. Paratypes: same sampling data as holotype, 4 females, 3 males, NSMT-Pc 10-16.

Measurements (Table 1). Tube length $490-621 \mathrm{~mm}(\mathrm{n}=8)$; outer width of top funnel opening $8.2-12.8 \mathrm{~mm}(\mathrm{n}=7)$; bottom outer width of top funnel $7.4-11.1 \mathrm{~mm}$ $(n=8)$; width of basal end of tube $0.8-2.3 \mathrm{~mm}(\mathrm{n}=8)$. Body length $271-516 \mathrm{~mm}(\mathrm{n}=8)$. Obturacular length $6.6-12.9 \mathrm{~mm}(\mathrm{n}=8)$. Vestimental length $21.9-43.1 \mathrm{~mm}(\mathrm{n}=8)$. Cuticular plaque length on vestimentum of paratype $78-88 \mu \mathrm{m}$ (mean $82 \mu \mathrm{m}, \mathrm{n}=4$ ), width $87-99 \mu \mathrm{m}$ (mean $94 \mu \mathrm{m}, \mathrm{n}=4$ ); length of plaques on trunk $49-85 \mu \mathrm{m}$ (mean
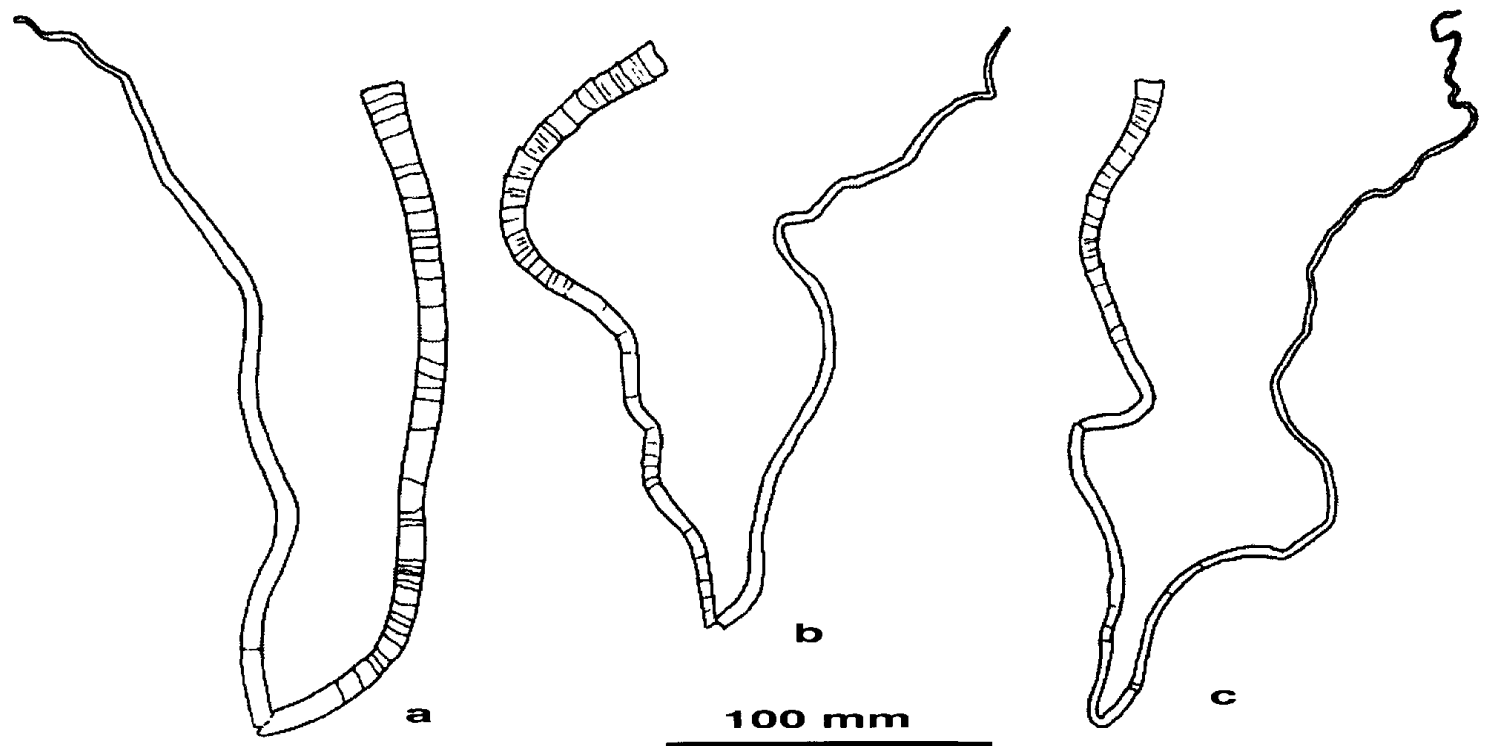

Fig. 1. Tubes of Lamellibrachia juni sp. nov., paratypes. a, NSMT-Pc 11; b, NSMT-Pc 12; c, NSMT-Pc 14. 
$73 \mu \mathrm{m}, \mathrm{n}=5$ ), width on trunk $80-98 \mu \mathrm{m}$ (mean $87 \mu \mathrm{m}, \mathrm{n}=4$ ). Vestimental length/obturacular length ratio $2.7-3.9(n=8)$. Vestimental length/obturacular width ratio $2.7-$ $5.7(n=8)$. Vestimental length/vestimental width ratio 3.1-6.0 $(n=8)$.

Description. Tube wall thin enough to be cut easily by dissecting scissors, with obvious growth collars in anterior region (Fig. 1a-c); top funnel largest; funnel opening 1.1-1.3 times wider than stem; anterior end of stem up to 11.5 times wider than basal end of tube.

Anterior face of obturaculum of adult bare, lacking secreted structures (Fig. 2b), surrounded by up to 35 pairs of branchial lamellae (Fig. 2c, Table 1). Each lamella formed by single series of fused branchial filaments with pimmules. Branchial lamellae partially hidden by up to 3 pairs of peripheral lamellar sheaths without pinnules (Fig. 2a-c). Obturaculum flared distally, lenticular in transverse section.

Anterior margin of vestimentum forming a short collar extending around base of obturaculum. Paired genital ciliated grooves of middorsal vestimentum bounded by prominent parallel ridges in male, but inconspicuous and not bounded

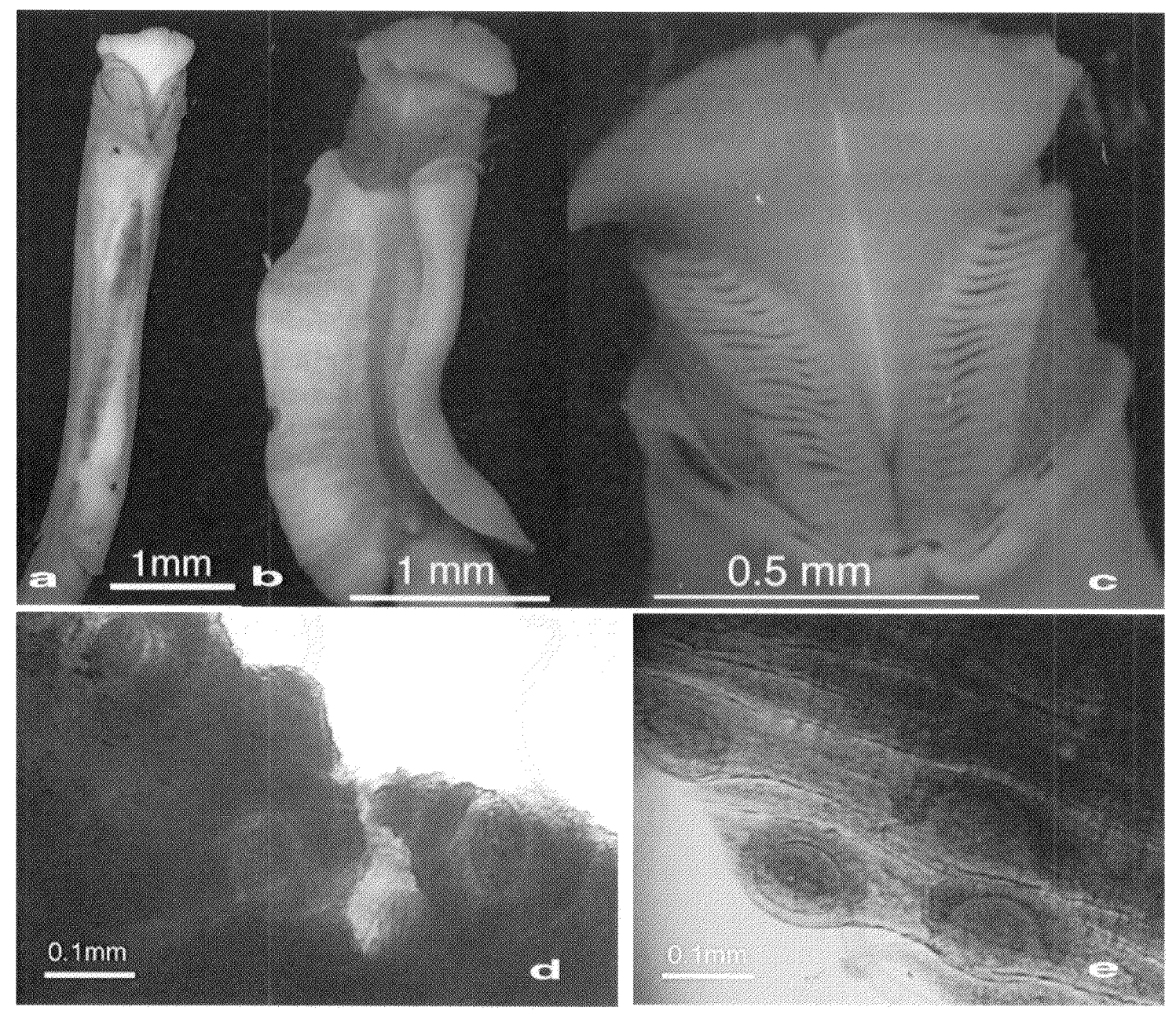

Fig. 2. Lamellbrachia junisp. nov. a, Anterior end, ventral view; b, anterior end, dorsal view; c, anterior end, dorsal view; d, cuticular plaques of vestimentum; e, cuticular plaques of trunk, a, Paratype, NSMT-Pe 10; b e, holotype, NSMT-Pc 9. 
Two new species of tubeworms

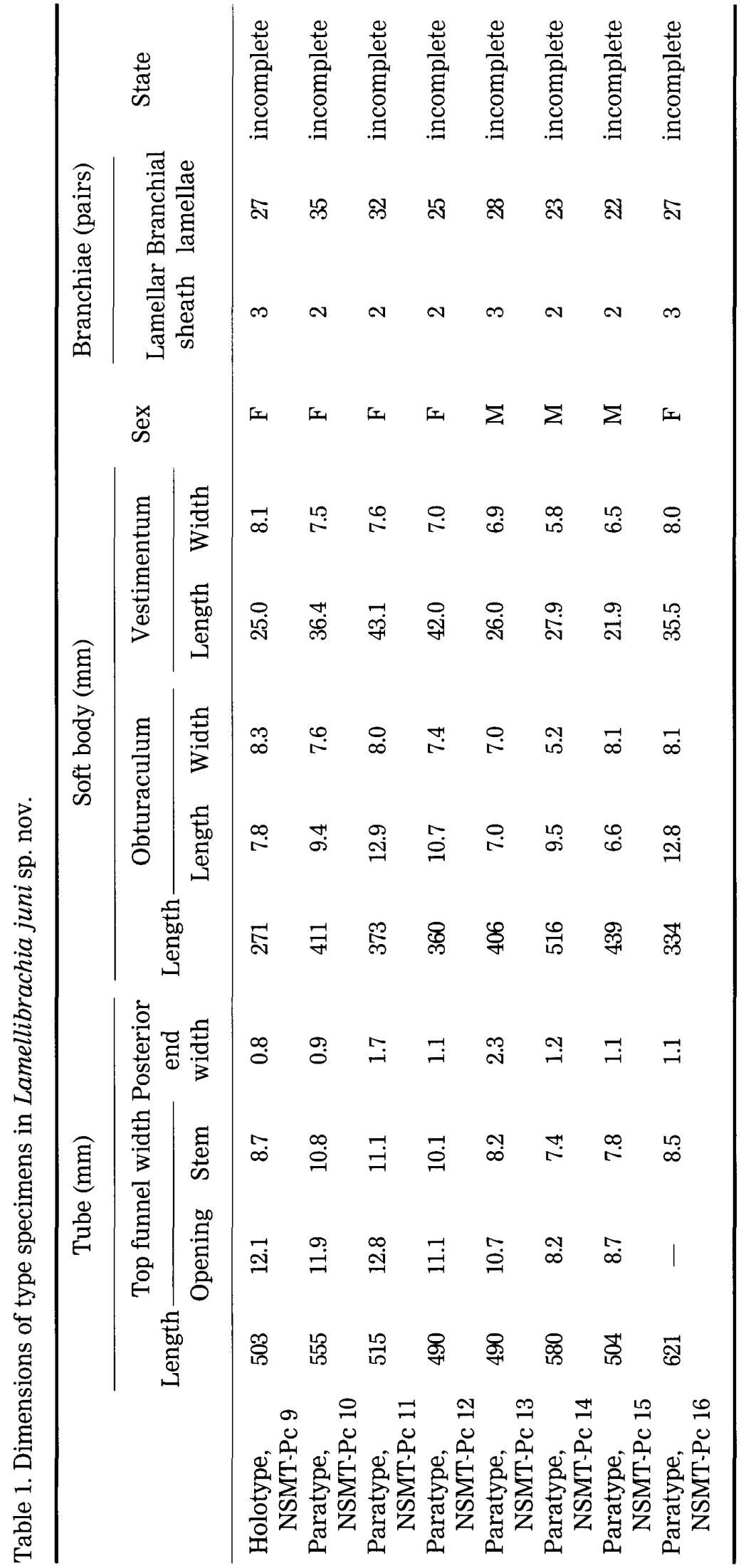







by ridges in female (Fig. 2b). Posteroventral margin of vestimentum broadly incised (Fig. 2a), ventral surface with numerous small papillae topped by oval cuticular plaques with raised anterior margins (Fig. 2d).

Trunk very long, covered with numerous small papillae topped by cuticular plaques of almost same size as vestimental ones (Fig. 2e, Table 1).

Opisthosome not observed in incomplete types.

Remarks. Lamellibrachia juni sp. nov. is the only species in the genus with a flexible and thin-walled tube. All other species have very stiff and thick-walled tubes, e.g., $1 \mathrm{~mm}$ measured in L. luymesi Van der Land and Nørrevang, 1975 (q.v.). Furthermore, L. juni has up to three pairs of lamellar sheaths, which is the smallest number in the genus. The maximal number of lamellar sheath pairs is 16 in $L$. columna Southward, 1991, six in the holotype of L. luymesi, eight in the specimens of $L$. luymesi from the Gulf of Mexico reported by Gardiner et al. (2003), seven in $L$. victori Mañé-Garzón and Montero, 1985, six in L. satsuma Miura, Tsukahara and Hashimoto, 1997, and four in L. barhami Webb, 1969 (Table 2). The last species differs from the new species in the size of the cuticular plaques; L. barhami has bigger plaques on the trunk than on the vestimentum, while L. juni has similarly sized plaques in both areas.

Etymology. The species epithet is based on the first name of a Japanese pioneer in deep-sea research, Professor Jun Hashimoto of Nagasaki University, who found numerous hot vent and cold seep sites around Japan.

Genus Oasisia Jones, 1985

Diagnosis (emended). Vestimentiferans characterized by basal blood supply of branchiae and subtriangular or Y-shaped transverse section of obturaculum. Vestimentum with posterior fold entire. Obturaculum with dorsally grooved stalk; face with saucer-like projection or elongated flap. Distal branchial filaments with pinnules.

Type species. Oasisia alvinae Jones, 1985, by monotypy.

Remarks. The diagnosis of the genus is emended to accommodate the present new species.

Oasisia fujikurai sp. nov. (Figs 3, 4, Table 3 )

Material examined. Holotype: Brothers Caldera, Shinkai 6500 Dive 852, 27 October $2004,34^{\circ} 51.671^{\prime} \mathrm{S}, 1^{\circ} 9^{\circ} 03.463^{\prime} \mathrm{E}, 1598 \mathrm{~m}$, sex unknown, NSM'T-Pc 17. Paratypes: same sampling data as holotype, 7 individuals including isolated opisthosome, sex unknown, NSMT-Pc 18-24. Non-types: same sampling data as holotype, 9 individuals, sex unknown, used only for measurement of tubes.

Measurements (Table 3). Length of selected tubes including those of paratypes $71-123 \mathrm{~mm}(\mathrm{n}=14)$; opening outer width of top funnel $1.7-2.8 \mathrm{~mm}(\mathrm{n}=14)$; bottom outer width of top funnel 1.4-2.2 mm $(n=14)$; width of basal end $0.3-1.2 \mathrm{~mm}$ $(n=14)$. Body length of almost complete paratypes $31-95 \mathrm{~mm}$ (mean $56.8 \mathrm{~mm}, \mathrm{n}=5$ ). Obturacular length $1.1-2.2 \mathrm{~mm}(\mathrm{n}=6)$. Vestimental length $3.8-4.7 \mathrm{~mm}(\mathrm{n}=6)$. Cuticu- 

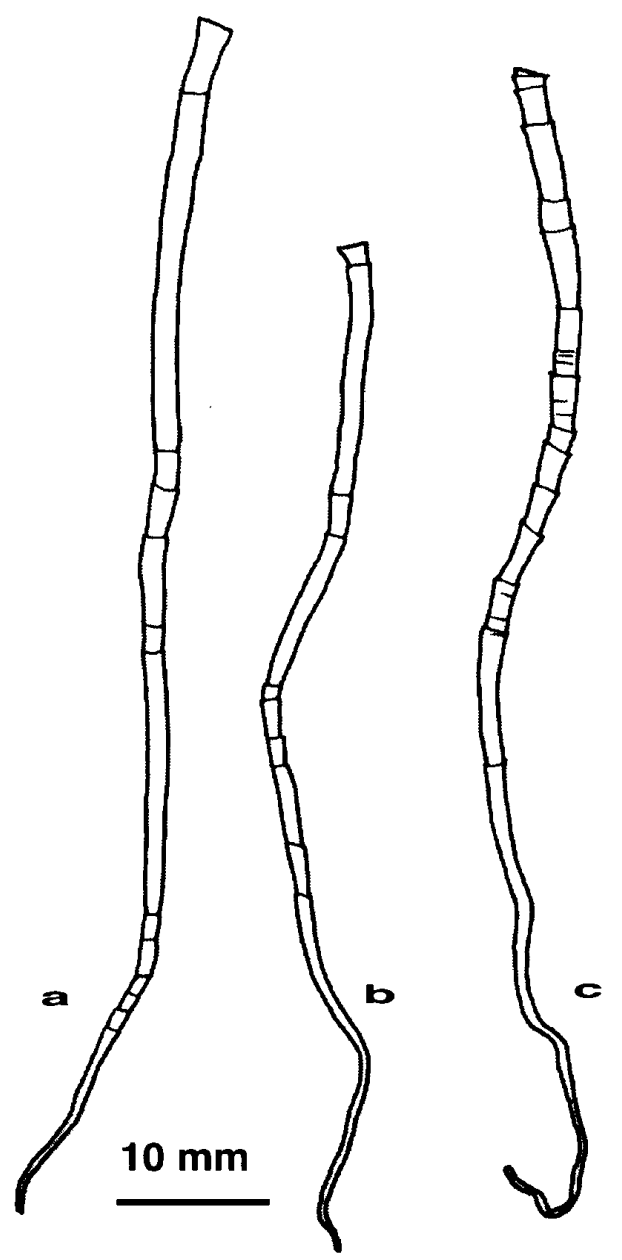

Fig. 3. Tubes of Oasisia fujikurai sp. nov., paratypes. a, NSMT-Pc 19; b, NSMT-Pc 22; c, NSMTPc 24.

lar plaque length on vestimentum of paratype $3446 \mu \mathrm{m}$ (mean $40 \mu \mathrm{m}, \mathrm{n}=10$ ), width $43-58 \mu \mathrm{m}$ (mean $51 \mu \mathrm{m}, \mathrm{n}=10$ ); length of plaques on trunk $34-50 \mu \mathrm{m}$ (mean $45 \mu \mathrm{m}$, $\mathrm{n}=10$ ), width on trunk 57-68 $\mu$ m (mean $62 \mu \mathrm{m}, \mathrm{n}=10$ ). Vestimental length/obturacular length ratio 2.7-3.9 $(\mathrm{n}=8)$. Vestimental length/obturacular width ratio 1.8-4.1 $(n=6)$. Vestimental length/vestimental width ratio 1.6-3.6 $(n=6)$.

Description. Tube thin enough to be cut by dissecting scissors, with obvious growth collars in anterior half (Fig. 3a-c). Top funnel largest, funnel opening 1.1-1.5 times wider than stem, anterior stem up to 5.8 times wider than basal end.

Obturaculum flimsy, subtriangular in transverse section with broad dorsal groove and prominent ventral ridge. Anterior face of obturaculum in adults sometimes with elongated, flap-like projection, without rod-like structure or lamina (Fig. 4a, c), with 6 to 8 pairs of branchial lamellae and sometimes additional single ventral unpaired lamella (Table 3). Each lamella formed of single series of fused branchial filaments; most filaments pinnulate on their distal halves, but posterior lamellae with several non-pinnulate filaments; dorsal non-pinnulate filaments longer and thinner than pinnulate ones (Fig. 4b), ventral non-pinnulate filaments as thick as pinnulate ones. Lamellar sheaths absent. 

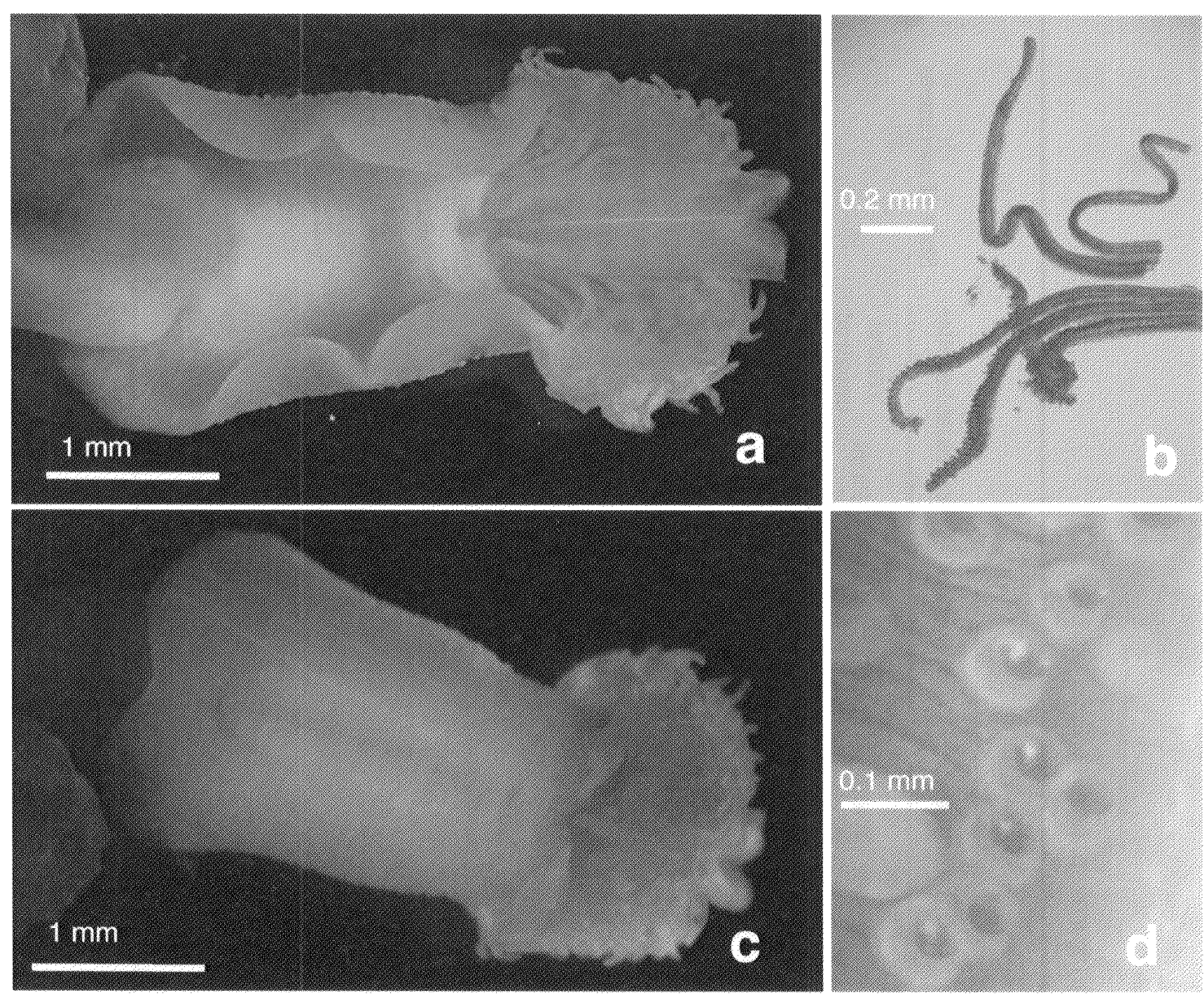

Fig. 4. Oasisia fujkwrai sp, nov, holotype, NSMT-Pc 17. a, Anterior end, dorsal view; b, distal tips of branchial filaments; $c$, anterior end, ventral view; d, cuticular plaque of vestimentum.

Anterior margin of vestimentum forming a broad collar covering base of obturaculum. Posteroventral margin of vestimentum entire (Fig. 4c), ventral surface with numerous small papillae topped by oval cuticular plaques (Fig. 4d).

Trunk long, covered with numerous small papillae topped by cuticular plaques; trunk plaques larger than vestimental ones.

Isolated opisthosome (NSMT-PC 24) preserved within type container with 9 anterior chaetigerous segments, 6 subsequent achaetigerous segments, and a terminal rounded segment. Chaetae arranged in single row along anterior margins of segments; most chaetae with 2 groups of denticles, anterior group including about 5 denticles in 2 rows, posterior group up to 12 denticles in 3 rows.

Remarks. The new species is classified in the emended genus Oasisia, which is characterized by the subtriangular shape in transverse section of the obturaculum, the stalk and face shape of the obturaculum, and the arrangement of the branchial pinnules. The new species differs from the type species by having up to eight pairs of branchial lamellae instead of up to 20 and by lacking a saucer-like medial obturacular structure.

Etymology. The species is named for Dr Katsunori Fujikura of JAMSTEC, 


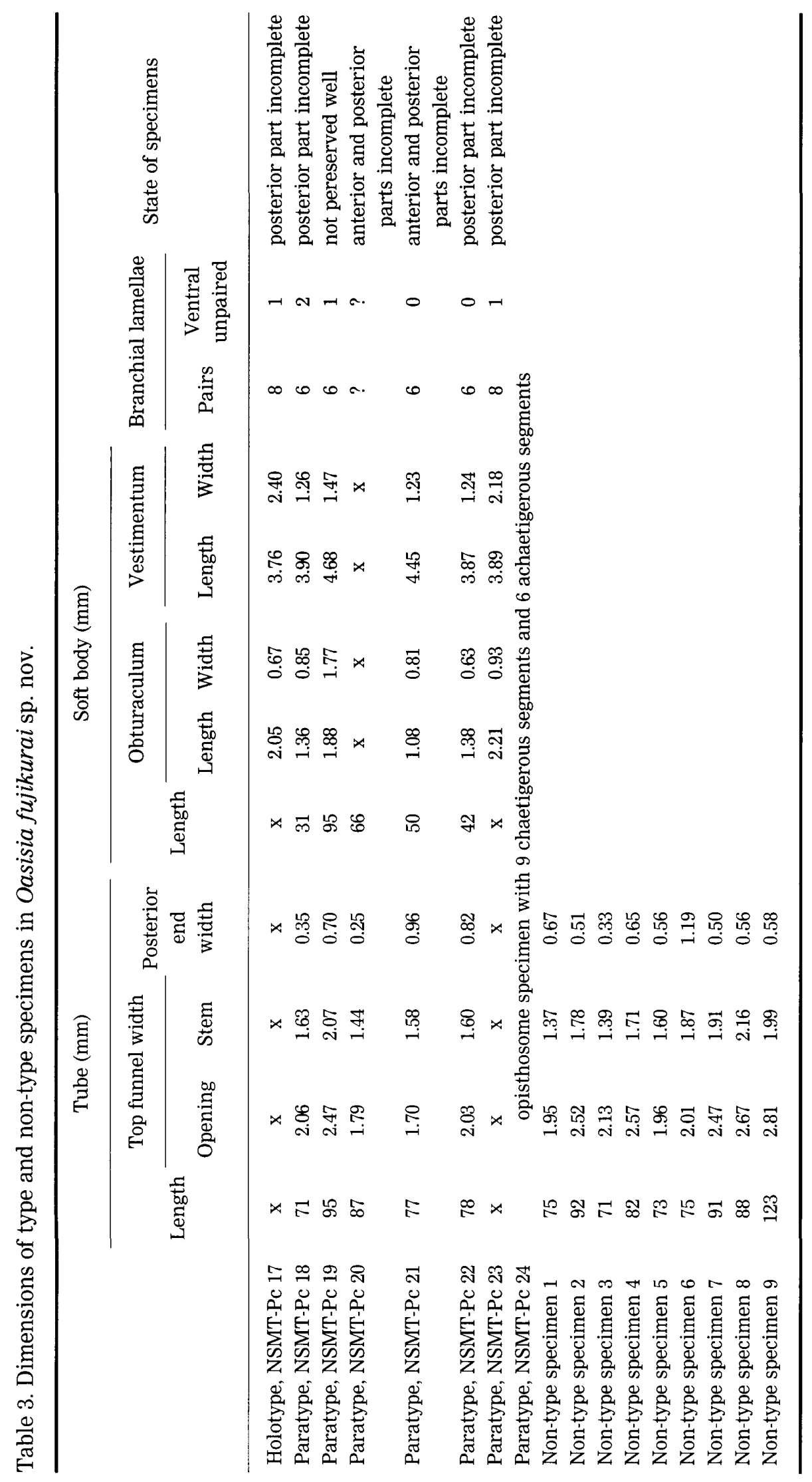


who provided the material examined in this study.

\section{Results of Molecular Phylogenetic Analysis}

Nucleotide sequences for $630 \mathrm{bp}$ in the COI gene were determined for three individuals each of Lamellibrachia juni sp. nov. and Oasisia fujikurai sp. nov. Sequences from the three specimens of each respective species were identical. These sequences will be entered in the GSDB, DDBJ, EMBL, and NCBI nucleotide sequence databases under accession numbers AB242858 (L. juni) and AB242857 (O. fujikurai).

We analyzed the phylogenetic relationships among the two new species and other described or tentatively recognized species for which the nucleotide sequences of the upstream region of the COI gene have been reported by Black et al. (1997), Gardiner et al. (2001), Kojima et al. (2001, 2002, 2003), McMullin et al. (2003), and Andersen et al. (2004), on the basis of the nucleotide sequence of a region common to all studies (618 bp). For the MP method, the TV/TS ratio of 4:1, which corresponded to the observed ratio (3.666: 1), was used.

In the neighbor-joining (NJ) and maximum parsimony (MP) trees (Fig. 5), Lamellibrachia juni formed a monophyletic group with an as yet undescribed species, Lamellibrachia sp. L7, which has been collected only at the DESMOS site in the Manus Basin (Kojima et al. 2003). Their joint monophyly was supported by $100 \%$ bootstrap values for both methods.

Oasisia fujikurai formed a monophyletic group with $O$. alvinae, and this was also supported by high bootstrap values (>94\%). Ridgeia piscesae Jones, 1985 formed a monophyletic clade with the Oasisia species on all MP trees, but this clade was supported by only a low bootstrap value (less than $50 \%$ ). On the other hand, the monophyly of this clade was supported in the NJ analysis by a relatively high bootstrap value $(70 \%)$. Tevnia jerichonana Jones, 1985 formed a monophyletic group with the Oasisia-Ridgeia clade on all MP trees and with Riftia pachyptila Jones, 1985 on the NJ tree, but these relationships were supported by low bootstrap values $(<50 \%)$ and the phylogenetic relationships among Tevnia, Riftia, and the Oasisia-Ridgeia clade are at best inconclusive.

\section{Discussion}

Oasisia, Teunia, and Riftia were erected each for a single species, while Ridgeia was erected for two species that were subsequently synonymized by Southward et al. (1995). These four genera formed a monophyletic group with the Alaysia-Arcovestia clade on all MP trees and on the NJ tree, based on molecular analysis (Fig. 5). Riftia is the only vestimentiferan genus characterized by an axial blood supply system to the branchiae (Table 4). Tevnia lacks obturacular saucers, as does Riftia, and thus differs from Oasisia and Ridgeia (Southward et al. 2002). The last two genera have been distinguished chiefly by the obturacular appendages and the number of rows of chaetal denticles (Jones 1985); however, with the synonymy of the two Ridgeia species (Southward et al. 1995) and the newly added morphological characters of the genus Oasisia in the present study, the dis- 


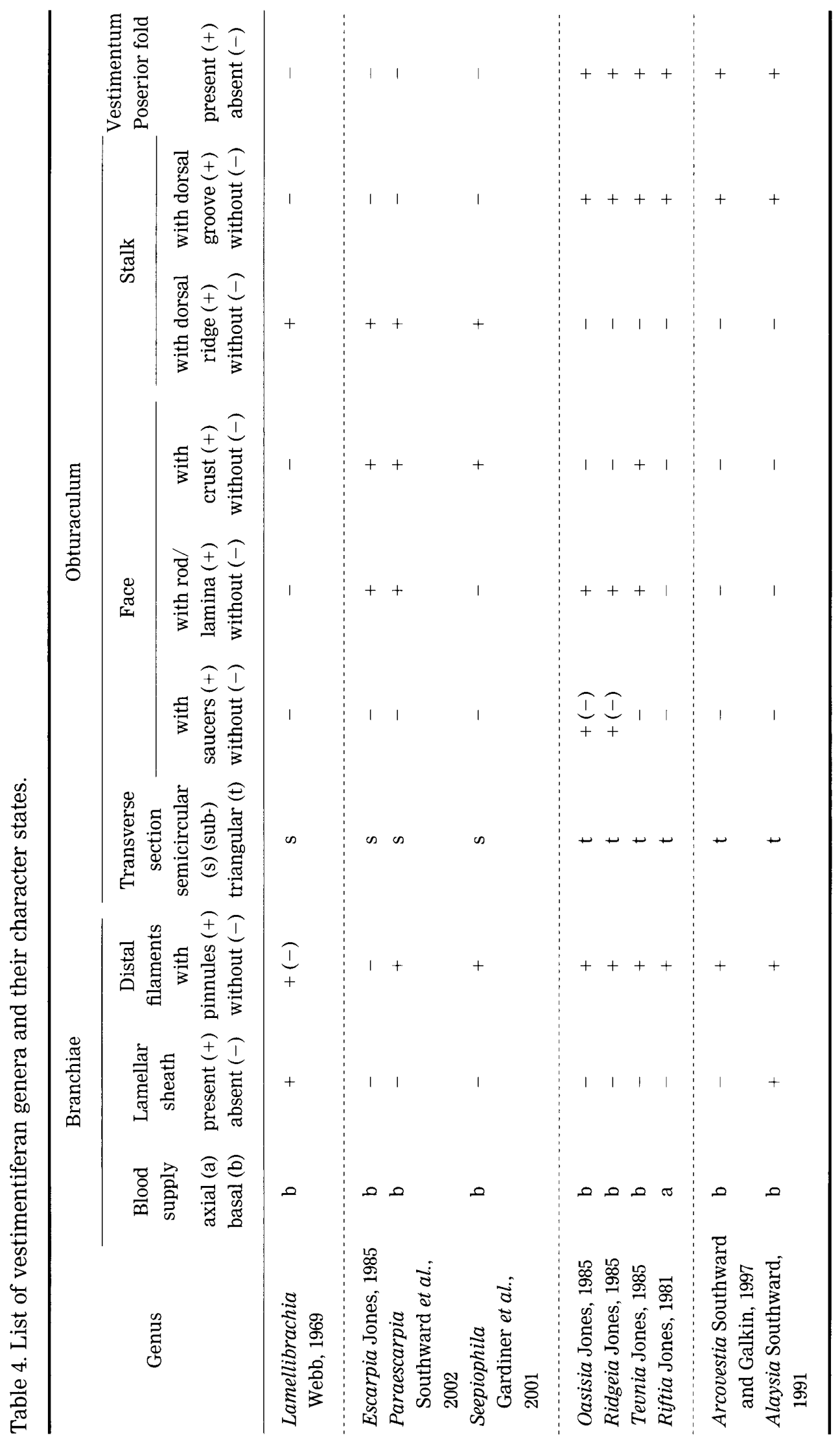




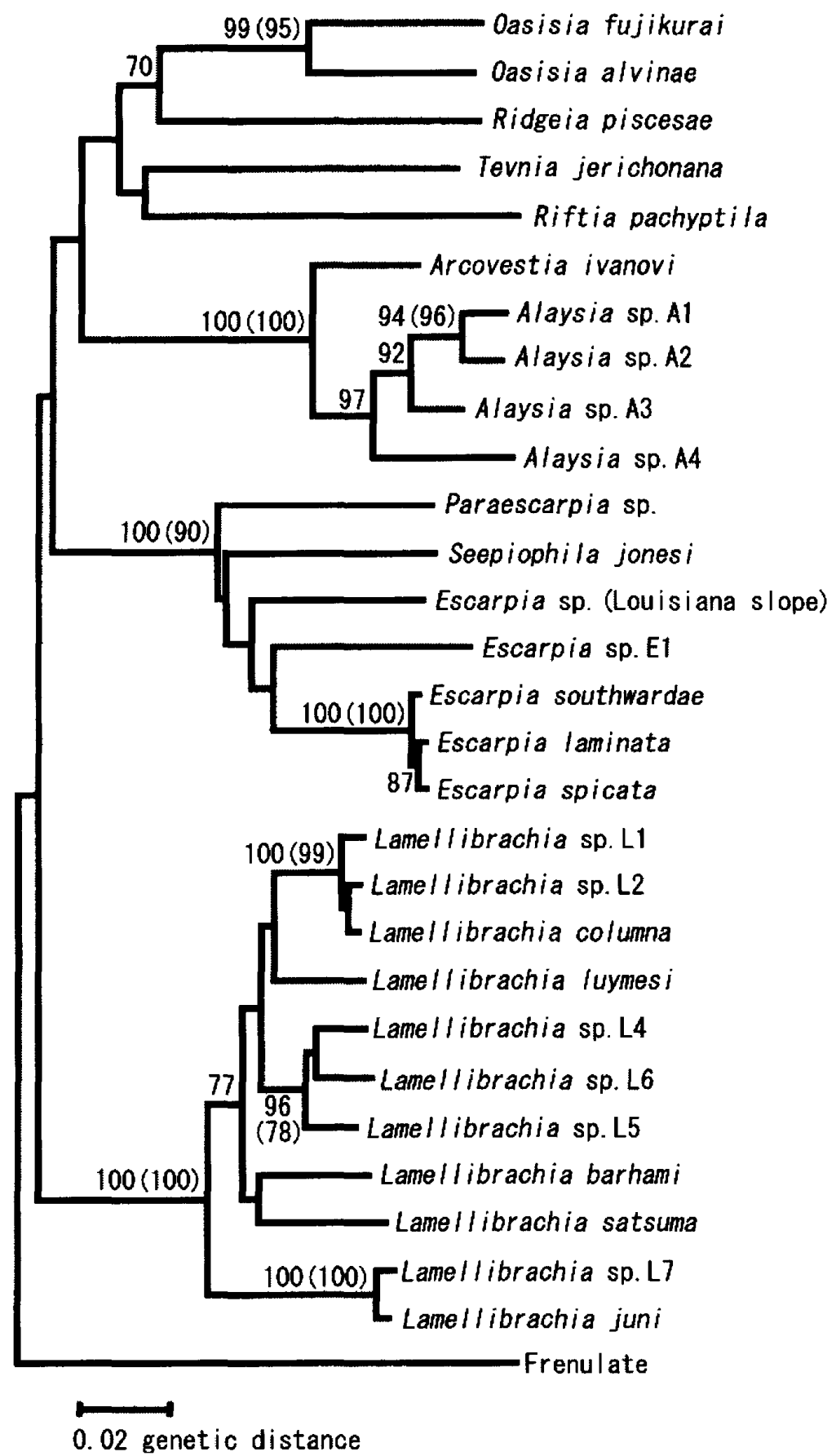

Fig. 5. Phylogenetic relationships among Lamellibrachia juni sp. nov., Oasisia fujikurai sp. nov., and other described or tentatively recognized species for which nucleotide sequences of the upstream region of the gene for cytochrome oxidase $c$ subunit I were available, as analyzed by the neighbor-joining (NJ) method. An unidentified frenulate (tentatively identified as Siboglinum sp.) was used as the outgroup. Bootstrap probabilities are shown above or below branches of clades that are supported by bootstrap values of more than $70 \%$. Bootstrap probabilities for the maximum-parsimony (MP) method are shown in parentheses when the values are greater than $70 \%$. 
tinctiveness of the obturacular appendages between the two genera becomes obscure and the morphology of the chaetae no longer distinguishes the two genera. We have classified Oasisia fujikurai in this genus by reason of the phylogenetic closeness demonstrated by the molecular analysis. Although the Oasisia-Ridgeia clade is clustered outside the other vestimentiferans with rather high bootstrap values (90\% in Hurtado et al. 2002 and $70 \%$ in the present study's neighbor-joining analysis) and no significant morphological difference between the genera is present, Oasisia and Ridgeia are maintained as independent genera as long as Ridgeia piscesae is placed outside the Oasisia species clade.

\section{Acknowledgments}

We express our sincere gratitude to Drs Peter Smith and Geoff Read (National Institute of Water \& Atmospheric Research Ltd., New Zealand) for their kind reading and commenting on a draft of the work. We are grateful to Drs Eve C. Southward, Mark J. Griger, and an anonymous referee for improvements to the submitted manuscript. We thank Dr Katsunori Fujikura (JAMSTEC) who provided the specimens for morphological study to the first author. This work was supported in part by a grant-in-aid for the first author from the Ministry of Education, Science, Sports, and Culture, Japan (No. 14540646).

\section{References}

Andersen, A. C., Hourdez, S., Marie, B., Jollivet, D., Lallier, F. H. and Sibuet, M. 2004. Escarpia southwardae sp. nov., a new species of vestimentiferan tube worm (Annelida, Siboglinidae) from West African cold seeps. Canadian Journal of Zoology 82: 980-999.

Black, M. B., Halanych, K. M., Maas, P. A. Y., Hoeh, W. R., Hashimoto, J., Desbruyères, D., Lutz, R. A. and Vrijenhoek, R. C. 1997. Molecular systematics of vestimentiferan tubeworms from hydrothermal vents and cold-water seeps. Marine Biology 130: 141-149.

Caullery, M. 1914. Sur les Siboglinidae, type nouveau d'invertébrés recueillis par l'expédition du Siboga. Bulletin de la Société Zoologique de France 39: 1-204.

Folmer, O., Black, M., Hoeh, W., Lutz, R. A. and Vrijenhoek, R. C. 1994. DNA primers for amplification of mitochondrial cytochrome $c$ oxidase subunit I from diverse metozoan invertebrates. Molecular Marine Biology and Biotechnology 3: 294-299.

Gardiner, S. L. and Hourdez, S. 2003. On the occurrence of the vestimentiferan tube worm Lamellibrachia luymesi van der Land and Nørrevang, 1975 (Annelida: Pogonophora) from hydrocarbon seep communities in the Gulf of Mexico. Proceedings of the Biological Society of Washington 116: 380-394.

Gardiner, S. L., McMullin, E. and Fisher, C. R. 2001. Seepiophila jonesi, a new genus and species of vestimentiferan tube worm (Annelida: Pogonophora) from hydrocarbon seep communities in the Gulf of Mexico. Proceedings of the Biological Society of Washington 114: 694-707.

Halanch, K. M., Lutz, R. A. and Vrijenhoek, R. C. 1998. Evolutionary origins and age of vestimentiferan tube-worms. Cahiers de Biologie Marine 39: 355-358.

Hurtado, L. A., Mateos, M., Lutz, R. A. and Vrijenhoek, R. C. 2002. Molecular evidence for multiple species of Oasisia (Annelida: Siboglinidae) at eastern Pacific hydrothermal 
vents. Cahiers de Biologie Marine 43: 377-380.

Jones, M. L. 1985. On the Vestimentifera, new phylum: six new species, and other taxa, from hydrothermal vents and elsewhere. Bulletin of the Biological Society of Washington 6: 117-158.

Kimura, M. 1980. A simple method for estimating evolutionary rate of base substitutions through comparative studies of nucleotide sequence. Journal of Molecular Evolution 16: 111-120.

Kojima, S. 1998. Paraphyletic status of Polychaeta suggested by phylogenetic analysis based on the amino acid sequences of elongation factor-1 $\alpha$. Molecular Phylogenetics and Evolution 9: 255-261.

Kojima, S., Ohta, S., Yamamoto, T., Miura, T., Fujiwara, Y., Fujikura, K. and Hashimoto, J. 2002. Molecular taxonomy of vestimentiferans of the western Pacific and their phylogenetic relationship to species of the eastern Pacific. II. Families Escarpiidae and Arcovestiidae. Marine Biology 141: 57-64.

Kojima, S., Ohta, S., Yamamoto, T., Miura, T., Fujiwara, Y. and Hashimoto, J. 2001. Molecular taxonomy of vestimentiferans of the western Pacific and their phylogenetic relationship to species of the eastern Pacific. I. Family Lamellibrachiidae. Marine Biology 139: 211219.

Kojima, S., Ohta, S., Yamamoto, T., Yamaguchi, T., Miura, T., Fujiwara, Y., Fujikura, K. and Hashimoto, J. 2003. Molecular taxonomy of vestimentiferans of the western Pacific and their phylogenetic relationship to species of the eastern Pacific. III. Alaysia-like vestimentiferans and relationships among families. Marine Biology 142: 625-635.

Kumar, S., Tamura, K., Jacobsen, I. B. and Nei, M. 2001. MEGA2: molecular evolutionary genetics analysis software. Arizona State University, Tempe, Arizona.

Mañé-Garzón, F. and Montero, R. 1985. Sobre una nueva forma de verme tubicola Lamellibrachia victori n. sp. (Vestimentifera). Proposicion de un nuevo phylum: Mesoneurophora. Revista de Biologia del Urguay 8: 1-28.

McHugh, D. 1997. Molecular evidence that echiurans and pognophorans are derived annelids. Proceedings of the National Academy of Sciences of the United States of America 94: 8006-8009.

McMullin, E. R., Hourdez, S., Schaeffer, S. W. and Fisher, C. R. 2003. Phylogeny and biogeography of deep-sea vestimentiferan tubeworms and their bacterial sybionts. Symbiosis 34 : $1-41$.

Miura, T., Tsukahara, J. and Hashimoto, J. 1997. Lamellibrachia satsuma, a new species of vestimentiferan worms (Annelida: Pogonophora) from a shallow hydrothermal vent in Kagoshima Bay, Japan. Proceedings of the Biological Society of Washington 110: 447-456.

Ronde, C. E. J. de, Hannington, M. D., Stoffers, P., Wright, I. C., Ditchburn, R. G., Reyes, A. G., Baker, E. T., Massoth, C. J., Lupton, J. E., Walker, S. L., Greene, R. R., Soong, C. W. R., Ishibashi, J., Lebon, G. T., Bray, C. J. and Resing, J. A. 2005. Evolution of a submarine magmatic-hydrothermal system: Brothers Volcano, southern Kermadec Arc, New Zealand. Economic Geology 100: 1096-1133.

Rouse, G. W. 2001. A cladistic analysis of Siboglinidae Caulllery, 1914 (Polychaeta, Annelida): formerly the phyla Pogonophora and Vestimentifera. Zoological Journal of the Linnean Society 132: 55-80.

Rouse, G. W. and Fauchald, K. 1997. Cladistics and polychaetes. Zoologica Scripta 26: 269-301.

Saitoh, N. and Nei, M. 1987. The neighbour-joining method: a new method for reconstructing phylogenetic trees. Molecular Biology and Evolution 10: 471-483.

Schulze, A. 2003. Phylogeny of Vestimentifera (Siboglinidae, Annelida) inferred from mor- 
phology. Zoologica Scripta 32: 321-342.

Southward, E. C. 1991. Three new species of Pogonophora, including two vestimentiferans, from hydrothermal sites in the Lau Back-arc Basin (Southwest Pacific). Journal of Natural History 25: 859-881.

Southward, E. C., Schulze, A. and Tunnicliffe, V. 2002. Vestimentiferans (Pogonophora) in the Pacific and Indian Oceans: a new genus from Lihir Island (Papua New Guinea) and the Java Trench, with the first report of Arcovestia ivanovi from the North Fiji Basin. Journal of Natural History 36: 1179-1197.

Southward, E. C., Tunnicliffe, V. and Black, M. 1995. Revision of the species of Ridgeia from northeast Pacific hydrothermal vents with a redescription of Ridgeia piscesae Jones (Pogonophora: Obturata=Vestimentifera). Canadian Journal of Zoology 73: 282-295.

Swofford, D. L. 2002. PAUP*. Phylogenetic Analysis Using Parsimony (*and other Methods), Version 4.0 b10. Sinauer Associates, Sunderland, Massachusetts.

Van der Land, J. and Nørrevang, A. 1975. The systematic position of Lamellibrachia (Annelida, Vestimentifera). Zeitschrift für Zoologische Systematik und Evolutionsforschung, Sonderheft 1975: 86-101.

Van der Land, J. and Nørrevang, A. 1977. Structure and relationships of Lamellibrachia (Annelida, Vestimentifera). Det Kongelige Danske Videnskabernes Selskab Biologiske Skrifter 21: 1-102, pls 1-26.

Webb, M. 1969. Lamellibrachia barhami gen. nov. sp. nov. (Pogonophora) from the northeast Pacific. Bulletin of Marine Science 19: 18-47.

Williams, N. A., Dixon, D. R., Southward, E. C. and Holland, P. W. H. 1993. Molecular evolution and diversification of the vestimentiferan tube worms. Journal of the Marine Biological Association of the United Kingdom 73: 437-452. 